\title{
Pengelolaan kelas Pendidikan Pancasila dan Kewarganegaraan dalam meningkatkan disiplin belajar
}

\author{
Yudi Firmansyah ${ }^{a, 1^{*}}$, Erwin Susanto ${ }^{b, 2}$, Muhammad Mona Adha ${ }^{c, 3}$ \\ ab Pendidikan Pancasila dan Kewarganegaraan, Universitas Buana Perjuangan Karawang, Indonesia \\ c Pendidikan Pancasila dan Kewarganegaraan, Universitas Lampung, Indonesia \\ ${ }^{1}$ yudifirmansyah@ubpkarawang.ac.id* \\ *korespondensi penulis
}

\begin{abstract}
ABSTRAK
Penelitian ini bertujuan menjelaskan bagaimana peran guru Pendidikan Pancasila dan Kewarganegaraan (PPKn) sebagai pengelola kelas dalam meningkatkan disiplin belajar siswa. Penelitian ini menggunakan pendekatan kualitatif dengan metode deskriptif. Subjek dalam penelitian ini adalah guru Pendidikan Pancasila dan Kewarganegaraan (PPKn) serta siswa dari kelas VIII. Teknik pengumpulan data menggunakan observasi, wawancara dan dokumentasi. Teknik analisis dilakukan dengan tiga alur tahap kegiatan yaitu reduksi data, penyajian data dan kesimpulan. Hasil dari penelitian ini dalam meningkatkan disiplin belajar siswa, guru Pendidikan Pancasila dan Kewarganegaraan (PPKn) sebagai pengelola kelas melakukan upaya dengan mengatur kelas agar tertib, menerapkan peraturan tata tertib untuk disiplin dalam belajar dan memberikan sanksi kepada siswa yang tidak disiplin dalam belajar. Rekomendasi penelitian ini, bagi kepala sekolah sebagai pemimpin dan pembuat kebijakan diharapkan dapat meningkatkan profesionalitas kerja guru sehingga guru dapat melakukan perannya dengan baik ketika mengajar serta memperketat dan meningkatkan siswa dalam mematuhi peraturan mengenai kedisiplinan di sekolah. Bagi guru, diharapkan untuk selalu memperhatikan perilaku disiplin siswa terutama saat kegiatan belajar di dalam kelas. Bagi siswa, diharapkan untuk lebih meningkatkan perilaku disiplin dalam mematuhi peraturan yang ada di sekolah atau di dalam kelas saat belajar. Bagi peneliti selanjutnya, semoga penelitian ini dapat menjadi bahan perbandingan dan referensi serta dapat dikembangkan sebagai bahan penelitian selanjutnya.
\end{abstract}

\section{ABSTRACT}

The purpose of this research is to explain the role of the teacher of Pancasila and Civic Education (PPKn) as the class manager in improving the learning discipline of the 8th-grade students. This research used a qualitative approach with a descriptive method. The subjects of this research are the teacher of Pancasila and Civic Education (PPKn) and the 8th-grade students. The data in this research were collected through observations, interviews, and context documentation. The analysis of data was conducted in three stages; data reduction, data display, and conclusion drawing. The result of research shows that in improving students' learning discipline, the teacher of Pancasila and Civic Education (PPKn), as the class manager, had made an attempt to manage the class in order, had practiced the rules of discipline in class, and had punished students who break the rules of discipline in class. There are several recommendations from this research. The headmaster as the chief and the policymaker is expected to be able to improve teachers' work professionalism so they can teach better. The school also expected to be always strict and make sure the students follow the rules of discipline. For teachers, they are expected to always monitor students' behavior during learning activity in class. For students, they are expected to improve their behavior discipline in following both the rules of school and classroom. Additionally, for the next researcher, hopefully, this research can be used as the comparative study, the reference, and can be developed as the material for the next research.

\section{Informasi Artikel}

Diterima : 28 November 2019

Disetujui: 10 Januari 2020

Kata kunci:

Pengelolaan kelas

Pembelajaran PPKn

Disiplin belajar

Article's Information:

Received: 2 Januari 2020

Accepted: 25 Januari 2020

Keywords:

Class management

PPKn Learning

Learning discipline

Korespondensi: Yudi Firmansyah, yudifirmansyah@ubpkarawang.ac.id, Program Studi Pendidikan Pancasila dan Kewarganegaraan, Universitas Buana Perjuangan Karawang, Indonesia 
Yudi Firmansyah, Erwin Susanto, Muhammad Mona Adha. Peran Guru Pendidikan Pancasila dan Kewarganegaraan sebagai Pengelola Kelas dalam Meningkatkan Disiplin Belajar

\section{Pendahuluan}

Pendidikan merupakan kegiatan yang hanya dapat dilakukan oleh manusia. Ruang lingkup lapangan pendidikan mencakup semua pengalaman dan pemikiran manusia tentang pedidikan. Undang-undang Sistem Pendidikan Nasional No. 20 Tahun 2003 menyatakan bahwa: "Pendidikan adalah usaha sadar dan terencana dalam mewujudkan suasana belajar dan proses pembelajaran agar peserta didik secara aktif mengembangkan potensi dirinya untuk memiliki kekuatan spiritual keagamaan, pengendalian diri, kepribadian, kecerdasan, akhlak mulia serta keterampilan yang diperlukan dirinya, masyarakat, bangsa dan Negara"

Mata pelajaran Pendidikan Pancasila dan Kewarganegaraan menekankan pada pembinaan terhadap perilaku warga Negara yang memiliki keberagaman untuk dapat menjalankan hak dan kewajibannya sebagai warga Negara Indonesia yang cerdas, terampil dan berkarakter. Susanto dan Komalasari (2015) bahwa: "Pembelajaran Pendidikan Pancasila dan Kewarganegaraan dengan memperhatikan sejumlah komponen belajar mengajar secara tepat, meliputi tujuan, bahan pelajaran, kegiatan belajar mengajar, metode, alat dan sumber serta evaluasi akan menunjang suasana pembelajaran yang senantiasa membelajarkan tiga kompetensi dasar yang harus dimiliki oleh siswa, yaitu: pertama, pengetahuan kewarganegaraan. Kedua, kecakapan kewarganegaraan. Ketiga, watak kewarganegaraan".

Guru Pendidikan Pancasila dan Kewarganegaraan dapat membina perilaku siswa melalui pembelajarannya yang berkaitan tentang nilai-nilai, etika dan sopan santun serta melalui perannya sebagai pengelola kelas dalam kegiatan belajar mengajar. Menurut Minsih (2018) keberhasilan pembelajaran di kelas sangat ditentukan oleh guru. Kegiatan guru di dalam kelas meliputi dua hal pokok, yaitu mengajar dan mengelola kelas. Pengelolaan kelas yang baik dapat membantu siswa belajar dengan tertib dan disiplin agar proses pembelajaran dapat tecapai sesuai dengan yang telah direncanakan.

Membentuk perilaku siswa salah satunya dengan menerapkan kedisiplinan di sekolah. Kedisiplinan merupakan hal yang sangat penting terutama bagi siswa. Widi, Saraswati dan Dayakisni (2017) menyatakan bahwa "Kedisiplinan merupakan perilaku yang terkendali penuh tanggung jawab dan masuk dalam perilaku yang baik". Kedisiplinan adalah bagian dari suatu pendidikan yang berguna untuk menjaga hal-hal yang dapat mengganggu atau menghambat kelancaran proses pendidikan. Masalah disiplin belajar siswa seperti mengobrol saat kegiatan belajar mengajar, tidur di dalam kelas saat guru mengajar, keadaan kelas yang tidak beraturan dan lain sebagainya dapat menghambat dan mengganggu proses pembelajaran. Peran guru di dalam pengelolaan kelas di dalam meningkatkan kedisiplinan belajar siswa, sekaligus mampu mengembangkan kecerdasan moral siswa itu sendiri (Abidin et al., 2015).

Menyikapi penjelasan di atas, mengenai disiplin belajar yang dapat mempengaruhi proses pembelajaran serta pentingnya peran guru dalam meningkatkan disiplin belajar siswa terutama guru Pendidikan Pancasila dan Kewarganegaraan yang dalam pembelajarannya lebih banyak mengajarkan tentang nilai-nilai, etika, sopan santun dan kedisiplinan. Maka peneliti melakukan observasi sementara mengenai kedisiplinan siswa di SMP Negeri 1 Telagasari.

Hasil observasi sementara menunjukan bahwa masih ada siswa yang berada di luar kelas pada saat jam pelajaran, siswa yang berpakaian tidak rapih dan siswa yang terlambat masuk kelas. Untuk itu, peneliti dapat menyimpulkan bahwa masih kurangnya perilaku disiplin siswa di sekolah terutama disiplin dalam belajar. Maka dari itu, diperlukan peran guru dalam meningkatkan disiplin belajar siswa. Berdasarkan permasalahan tersebut, peneliti melakukan penelitian terhadap peran guru Pendidikan Pancasila dan Kewarganegaraan sebagai Pengelola Kelas dalam Meningkatkan Disiplin Belajar. 


\section{Metode}

Penelitian ini menggunakan pendekatan kualitatif dengan metode deskriptif. Subjek dalam penelitian ini adalah guru Pendidikan Pancasila dan Kewarganegaraan serta 3 orang siswa dari kelas VIII SMPN 1 Telagasari. Keabsahan data menggunakan triangulasi sumber. Teknik pengumpulan data menggunakan observasi, wawancara dan dokumentasi. Teknik analisis data dilakukan dengan tiga alur tahap kegiatan yaitu, reduksi data, penyajian data kemudian penarikan kesimpulan.

\section{Hasil dan Pembahasan}

Hasil penelitian menunjukkan bahwa guru Pendidikan Pancasila dan Kewarganegaraan dalam meningkatkan disiplin belajar siswa melalui perannya sebagai pengelola kelas dengan mengatur kelas yang baik agar siswa tertib dan disiplin dalam belajar. Seperti membuat perencanaan dalam kegiatan belajar antara siswa dan guru agar proses pembelajaran dapat terlaksana dengan baik, guru melatih jiwa kepemimpinan siswa untuk membentuk karakter kepercayaan diri dalam diri siswa, mengajarkan cara untuk bertanggung jawab kepada siswa, membimbing siswa dalam membentuk organisasi kelas secara demokratis, membiasakan siswa untuk mandiri dalam melaksanakan tugas dan kewajibannya serta membiasakan perilaku siswa untuk berpartisipasi aktif dalam kegiatan belajar.

Peran guru di dalam mengarahkan dan membimbing siswa selama proses pembelajaran dan factor keteladanan dapat berpengaruh secara positif bagi diri siswa (Zulyan et al., 2014; Wijaya et al., 2020). Teori yang mengemukakan peran guru sebagai pengelola kelas terdapat dalam penelitian Hamidah (2018): "Guru sebagai pengelola kelas ialah orang yang mengelola dan mengatur. Tujuannya adalah menyediakan dan menggunakan kelas untuk bermacam-macam kegiatan belajar dan mengajar agar mencapai hasil belajar yang baik. Sebagai pengelola, guru berperan dalam menciptakan iklim belajar yang memungkinkan siswa dapat belajar secara nyaman. Melalui pengelolaan kelas yang baik guru dapat menjaga kelas agar tetap kondusif untuk terjadinya proses belajar siswa"

Selain itu guru Pendidikan Pancasila dan Kewarganegaraan SMPN 1 Telagasari sebagai pengelola kelas untuk membuat siswa disiplin dalam belajar dengan menciptakan lingkungan atau suasana belajar yang menyenangkan agar siswa tidak merasa bosan atau jenuh saat kegiatan belajar mengajar. Sesuai dengan pendapat Minsih (2018) tentang peran guru dalam pengelolaan kelas sebagai berikut: "Pengelolaan kelas perlu menciptakan suasana gembira atau menyenangkan di lingkungan sekolah melalui pengelolaan kelas, dengan menjalin keakraban antara guru-siswa, maka guru dapat mengarahkan siswa dengan lebih mudah untuk mendorong dan memotivasi semangat belajar siswa".

Dengan menciptakan lingkungan belajar yang nyaman dan menyenangkan serta dapat mengatur kelas dengan baik melalui peran guru sebagai pengelola kelas dapat membuat siswa belajar dengan tertib dan disiplin. Guru Pendidikan Pancasila dan Kewarganegaraan SMP Negeri 1 Telagasari sebagai pengelola kelas dalam meningkatkan disiplin belajar melakukan peranannya dengan mengatur kelas yang baik, menciptakan lingkungan belajar yang nyaman dan menyenangkan agar siswa dapat disiplin dalam melaksanakan kegiatan belajar. Namun, hal tersebut tidak menjamin semua siswa dapat berperilaku disiplin di dalam kelas. Beberapa dari siswa masih menunjukan perilaku yang kurang disiplin dalam belajar seperti mengobrol di dalam kelas saat kegiatan belajar berlangsung atau terlambat memasuki kelas.

Perilaku siswa yang masih kurang disiplin dalam belajar tentunya dipengaruhi oleh beberapa faktor. Menurut guru Pendidikan Pancasila dan Kewarganegaraan faktor-faktor yang memengaruhi siswa tidak disiplin dalam belajar adalah faktor instrinsik contoh psikologi peserta didik seperti minat, motivasi, bakat dan kemampuan. Kemudian faktor ekstrinsik seperti lingkungan sosial masyarakat dan lingkungan sosial keluarga. 
Sesuai dengan teori yang mengemukakan faktor-faktor yang memengaruhi disiplin belajar siswa menurut Suradi (2011) adalah sebagai berikut:

a. Faktor ekstrinsik

1) Faktor non-sosial, seperti keadaan udara, waktu, tempat dan peralatan maupun media yang dipakai untuk belajar.

2) Faktor sosial terdiri atas lingkungan keluarga, lingkungan sekolah dan lingkungan masyarakat.

b. Faktor intrinsik

1) Faktor psikologi, seperti minat, motivasi, bakat, konsentrasi, dan kemampuan kognitif.

2) Faktor fisiologis, yang termasuk dalam faktor fisiologis antara lain pendengaran, penglihatan, kesegaran jasmani, kekurangan gizi, kurang tidur dan sakit yang diderita.

Berdasarkan faktor-faktor tersebut yang dapat memengaruhi disiplin belajar siswa, peran guru Pendidikan Pancasila dan Kewarganegaraan sebagai pengelola kelas dalam meningkatkan disiplin belajar melakukan upaya dengan menerapkan peraturan tata tertib disiplin belajar di dalam kelas, seperti salah satunya dilarang untuk menyontek saat mengerjakan tugas, dilarang mengobrol atau berisik saat guru menerangkan pelajaran dan siswa dilarang tidur di dalam kelas saat guru mengajar. Apabila siswa melanggar dengan berperilaku tidak disiplin dalam belajar, guru Pendidikan Pancasila dan Kewarganegaraan memberikan sanksi berupa teguran, memberikan nasehat dengan bijaksana, memberikan motivasi belajar dan tentunya selalu mencontohkan teladan yang baik kepada siswa untuk disiplin (Putri et al., 2020; Perdana et al., 2020). "Peran guru dalam membentuk wawasan kebangsaan guru tidak hanya memotivasi atau memberikan nasehat saja, tetapi menjadi contoh bagi siswa untuk mencintai tanah air dan memberi contoh bagaimana menaati peraturan sekolah dan disiplin dalam belajar" (Nugraha, 2017)

Menurut Darmadi (2015) yang berpendapat mengenai peran guru sebagai pengelola kelas yaitu sebagai berikut:

"Peran guru sebagai pengelola kelas, hendaknya diwujudkan dalam bentuk pengelolaan kelas sebagai lingkungan belajar. Lingkungan belajar diatur dan diawasi agar kegiatan-kegiatan belajar terarah pada tujuan-tujuan pendidikan yang telah ditetapkan"

Peran guru sebagai pengelola kelas harus dapat mengatur kelas dengan baik dan tertib serta menciptakan suasana pembelajaran yang nyaman dan menyenangkan agar siswa disiplin disetiap melaksanakan kegiatan belajar. Berdasarkan penjelasan tersebut dapat disimpulkan bahwa, peran guru Pendidikan Pancasila dan Kewarganegaraan sebagai pengelola kelas dalam meningkatkan disiplin belajar siswa dengan mengatur kelas yang baik dan tertib, menerapkan peraturan tata tertib untuk disiplin belajar di dalam kelas dan memberikan sanksi kepada siswa yang tidak disiplin dalam belajar.

\section{Simpulan}

Berdasarkan hasil penelitian dan pembahasan, maka peneliti dapat menyimpulkan bahwa peran guru Pendidikan Pancasila dan Kewarganegaraan sebagai pengelola kelas dalam meningkatkan disiplin belajar siswa dengan mengatur kelas agar tertib dalam belajar, menerapkan peraturan tata tertib untuk disiplin dalam belajar serta memberikan sanksi kepada siswa yang tidak disiplin dalam belajar. Saran dalam penelitian ini, bagi kepala sekolah sebagai pemimpin dan pembuat kebijakan diharapkan dapat menigkatkan profesionalitas guru sehingga guru dapat melakukan perannya sebagai pengelola kelas dengan baik serta memperketat dan meningkatkan perilaku siswa untuk disiplin dalam mematuhi peraturan yang ada di sekolah. 
Bagi guru, diharapkan untuk selalu memperhatikan perilaku disiplin siswa terutama saat kegiatan belajar di dalam kelas agar kegiatan belajar mengajar dapat berjalan dengan tertib dan tujuan pembelajaran dapat tercapai dengan baik. Bagi siswa, diharapkan untuk lebih meningkatkan perilaku disiplin dalam mematuhi peraturan yang ada di sekolah atau di dalam kelas saat belajar seperti membiasakan diri untuk berperilaku disiplin dalam belajar dengan memperhatikan guru saat mengajar, tidak mengobrol serta berpakaian rapih dan sebagainya. Bagi peneliti selanjutnya yang akan meneliti dengan tema yang sama semoga penelitian ini dapat menjadi bahan perbandingan dan referensi serta dapat dikembangkan sebagai bahan penelitian selanjutnya.

\section{Referensi}

Abidin, R. F., Pitoewas, B., \& Adha, M. M. (2015). Peran Guru Pendidikan Kewarganegaraan dalam Mengembangkan Kecerdasan Moral Siswa. Jurnal Kultur Demokrasi, 3 (1).

Darmadi, H. (2016). Tugas, Peran, Kompetensi, dan Tanggung Jawab Menjadi Guru Profesional. Edukasi: Jurnal Pendidikan, 13(2), 161-174.

Hamidah, Millatun. 2018. Upaya Guru Dalam Meningkatkan Kedisiplinan Siswa SMK Muhammadiyah Parakan Tangerang Selatan. Skripsi. Jakarta: Program Studi Agama Islam Universitas Muhammadiyah Jakarta.

Minsih, M., (2018). Peran Guru dalam Pengelolaan Kelas. Profesi Pendidikan Dasar, 1(1), pp.20-27.

Nugraha, N. (2017). Peran Guru dalam Upaya Pembentukan Wawasan Kebangsaan pada Siswa Kelas VIII SMPN 1 Barat Kabupaten Magetan Tahun Ajaran 2015/2026". Citizenchip Jurnal Pancasila dan Kewarganegaraan, 5(1), 13-23).

Perdana, D. R., Adha, M. M. 2020. Implementasi Blended Learning untuk Penguatan Pendidikan Karakter Pada Pembelajaran Pendidikan Kewarganegaraan. Citizenship Jurnal Pancasila dan Kewarganegaraan, 8 (2): 89-101.

Putri, D. S., Adha, M. M., \& Pitoewas, B. (2020). The Problems of Implementing Blended Learning Class in Civic Education Students, University of Lampung. Universal Journal of Educational Research, 8(3D): 106-114.

Suradi, S.Pd, M.Si. 2011. Pentingnya Penerapan Disiplin Siswa di SMK Negeri 1 Mesuji Raya. Smkn1mesujiraya.blogspot.com. (diakses pada 20 Juni 2012)

Susanto, E., \& Komalasari, K. (2015). PENGARUH PEMBELAJARAN, HABITUASI DAN EKSTRAKURIKULER TERHADAP PEMBENTUKAN CIVIC DISPOSITION SISWA SMA NEGERI SE-KOTA BANDAR LAMPUNG. Jurnal Ilimiah Mimbar Demokrasi, 15(1), 60-68.

Undang-Undang Nomor 20 Tahun 2003 Tentang Sistem Pendidikan Nasional. 2003. Jakarta: Sekretariat Negara.

Widi, E. N. N., Saraswati, P., \& Dayakisni, T. (2017). Kedisiplinan Siswa-Siswi SMA Ditinjau dari Perilaku Shalat Wajib Lima Waktu. Jurnal Psikologi Islam, 4(2), 135-150.

Wijaya, A. K., Giyono, U., \& Adha, M. M. (2020). Kontribusi Pembelajaran Pendidikan Kewarganegaraan Menggunakan Model Role Playing untuk Pengembangan Keterampilan Intelektual Siswa. Jurnal Pendidikan Pancasila dan Kewarganegaraan, 1(2): 130-139.

Zulyan, S. V., Pitoewas, B., \& Adha, M. M. (2014). Pengaruh Keteladanan Guru Terhadap Sikap Belajar Peserta Didik. Jurnal Kultur Demokrasi, 2(2). 